\title{
TEISÉ
}

\section{KONSTITUCINIAI SANTYKIAI: SĄVOKOS PROBLEMATIKA IR ESMÉ}

\author{
Dr. Tomas Blinstrubis
}

Mykolo Romerio universiteto

Teisès fakulteto Viešosios teisès institutas

Mykolas Romeris University

Faculty of Law Institute of Public Law

Ateities g. 20, LT-08303 Vilnius, Lietuva

El.paštas t.blinstrubis@mruni.eu

\section{Santrauka}

Nors anaiptol ne kiekvienas teisès reguliuojamas santykis yra konstitucinis, teisès kalboje sqqvokai „konstituciniai santykiai“ dažniausiai pridedamas epitetas "teisiniai", todèl natūraliai kyla klausimas, ar jie apskritai gali büti neteisiniai. Šiame straipsnyje bandomos nagrinèti teisinés problemos susiaurinamos iki keliu salygiškai savarankišku, bet tarpusavyje glaudžiai susijusiu ir šio tyrimo objektą apibüdinančiu klausimu grupių. Viena ju aprépia klausimus, kylančius iš teorinès konstituciniu santykiu sampratos ir ju elementu analizés. Metodologiškai vadovaujantis konstitucines teisés, kaip valstybès aukščiausiosios teises, paradigma formuluojama pamatine tezé, kad iš Konstitucijos kylantys santykiai visada yra teisiniai santykiai (o teisiniai santykiai anaiptol ne visada yra konstituciniai); parodoma, kad konstitucinių santykių apibrèžtis teisiškai yra pakankama, nereikalaujanti tokius santykius papildomai apibrëžti kaip teisinius. Kitai probleminiu klausimu grupei priskirtini asmens pagrindiniu teisiu klausimai. Straipsnyje teigiama, kad pagrindinès teisès nèra konstituciniu santykiu objektas, o yra pats konstituciniu santykiu pamatas, ju determinantas, konstitutyvinis šiu santykiu elementas ir tai nera 
atsiejama nuo pačios konstitucionalizmo idejos ${ }^{1}$. Toks šio tyrimo problematikos išskaidymas ir išryškina pamatinę prielaidą: asmens-asmenų susivienijimų-valstybès santykiai yra ir turi büti subordinuoti vienai aukščiausiajai teisei, suderinančiai šių elementų sąveiką, - Konstitucijai. Straipsnio tikslas yra parodyti, kad šie santykiai neviršija Konstitucijos, t. y. jos teisinés galios bei vertybiu sistemos, ribų, nes tik aukščiausios teisès (formalios ir jurisprudencinès), o ne ordinarinès teisès reglamentuojami santykiai yra konstituciniai. Todel straipsnio tikslas ir yra atskleisti konstitucinių santykiu specifika konstitucinès teisès kaip aukščiausiosios teises sampratos kontekste ir atsakyti i klausima, ar įmanoma suformuluoti teisiškai pakankama konstituciniu santykiu definicija apimant visus klasikinius teisiniu santykiu elementus. Šiuo darbu taip pat siekiama paskatinti konstitucionalistus padiskutuoti konstituciniu santykiu sampratos klausimu. Straipsnyje analizuojama moderni konstitucines teisés samprata atskleidžiama ar net plètojama per naujai pateikiama konstituciniu santykiu samprata, todèl „tradicinès“ ir „modernios" koncepcijos sankirtos nagrinejimas lemia ir temos aktualumą bei šio straipsnio naujumą Lietuvos teisés moksle. Mokslinè doktrina šio straipsnio tyrimo objekto klausimu iki šiol nèra peržengusi oficialios konstitucinès doktrinos atskleisto turinio ribu, daugelyje analizuotu konstitucinés teisés darbu paprastai vengiama apibrèžti konstitucinius santykius, arba konstitucinių santykių specifika iš viso nèra atskleidžiama per klaidingus bandymus isprausti juos i definicinius rèmus. Kad tokiu klausimu kelimas nebandant suformuluoti galimu argumentuotu atsakymu variantu netaptu savitikslis, tema nagrinejama taikant klasikinius mokslinio tyrimo metodus: istorini, lyginamosios teisètyros, teleologini (normų tikslo - objektyvusis elementas, teisés akto leidejo valios - subjektyvusis elementas), lingvistinio teisès aiškinimo, sintezès, sisteminès analizès.

1 ,Visuomenè, kurioje teisių garantavimas nėra užtikrinamas ir kurioje nėra įtvirtintas valdžių padalijimas, neturi Konstitucijos“, - skelbiama 1958 m. Prancūzijos Konstitucijos sudedamosios dalies $1789 \mathrm{~m}$. Žmogaus ir piliečio teisių deklaracijos XVI straipsnyje. Constitution de la République française du 4 octobre 1958. 
Reikšminiai žodžiai: Konstitucija; konstitucinė jurisprudencija; konstituciniai santykiai; teisiniai santykiai.

\section{Ivadas}

„Svarbiausioji mūsų gyvenimo dalis - tai savitarpiniai vienų su kitais santykiai ir kiekvieno iš mūsų santykiai su žmonių draugijomis ir su didžiausiu iš tų draugijų - valstybe. Tuos santykius tvarko dora ir teisè. “2 Nagrinejjant minètą asmens-,,žmoniu draugijü“-valstybès santykių schemą svarbiausia laikytis aksiomos, kad „bet kokių teisinių tyrimų išeities pozicija viena - Konstitucija“"3. Pilietinei tautai igyvendinant savo suverenias galias $1992 \mathrm{~m}$. spalio $25 \mathrm{~d}$. referendume priimta Lietuvos Respublikos Konstitucija ${ }^{4}$ (toliau - Konstitucija) - „pirminè teisė ir teisinès galios, ir turinio atžvilgiu“ ${ }^{\text {. }}$.Konstitucija yra aukščiausioji teisè. Ji nubrěžia gaires visai teisès sistemai - visa teisès sistema kuriama Konstitucijos pagrindu. “6 „Konstitucijoje negali būti ir nèra spragų ar vidinių prieštaravimų “7, ,vadinasi, negali būti ir nèra tokio žemesnès

${ }_{2}$ Leonas, P. Teisè ir dora. Leonas, Petras. Raštai. T. 3, Teisinè publicistika; Pergyvenimai ir atsiminimai; Teisinis palikimas; Bibliografija. Sudarè V. Andriulis. Vilnius: Teisinès informacijos centras, 2005, p. 78.

3 Jarašiūnas, E. Teisminès valdžios organizacijos ir veiklos konstitucinès problemos (teisminès valdžios visavertiškumas, teismų sistemos bei teisèjų ir teismų nepriklausomumas). Lietuvos konstitucine teisé: raida, institucijos, teisiu apsauga, savivalda: kolektyvinè monografija. Vilnius: Mykolo Romerio universiteto Leidybos centras, 2007, p. 295.

4 Lietuvos Respublikos Konstitucija įsigaliojo $1992 \mathrm{~m}$. lapkričio 2 d., paskelbta 1992 m. lapkričio 30 d. Valstybès žinios. 1992, Nr. 33-1014. Pakeitimai: ibid., 1996. Nr. 64-1501, 122-2863; 2002, Nr. 65-2629; 2003, Nr. 14-540, 32-1315, 32-1316; 2004, Nr. 111-4123, 111-4124; 2006, Nr. 48-1701.

5 Jarašiūnas, E. Konstitucija ir įstatymas: kelios interpretavimo problemos. Konstitucijos aiškinimas ir tiesioginis taikymas. [Sudarè V. Rinkevičius]. Vilnius: Lietuvos Respublikos Konstitucinis Teismas, 2002, p. 238.

6 Konstitucinio Teismo $2004 \mathrm{~m}$. gegužès 25 d. nutarimo motyvuojamosios dalies II skyriaus 1 punktas. Valstybès žinios. 2004, Nr. 85-3094.

7 Konstitucinio Teismo $2006 \mathrm{~m}$. kovo 28 d. nutarimo motyvuojamosios dalies II skyriaus 12.2 punktas. Ibid., 2006, Nr. 36-1292. 
galios teisès aktuose nustatyto teisinio reguliavimo, kurio nebūtų galima vertinti jo atitikties Konstitucijai požiūriu“" . „Konstitucija yra $<\ldots>$ visų kitų teisès aktų teisiškumo ir legitimumo matas ${ }^{\text {“9 }}$, tiksliau, ji „yra vienintelis [ordinarinès teisès ${ }^{10}$ ] [intarpas autoriaus - T. B. pastaba] teisiškumo matas" $^{\text {"11 }}$, ne tik visos nacionalinès teisès, bet „ir visos kitos atitinkamoje valstybejje galiojančios ir taikomos teisès teisiškumo matas“12. „Konstitucija - tiesiogiai taikomas aktas, ji leidžia kvestionuoti konstitucingumo aspektu bet kokị ordinarinị teisinị reguliavimą - ne tik atitinkamame ordinarinès teisès akte eksplicitiškai arba implicitiškai įtvirtintas nuostatas, bet ir jų nebuvimą, t. y. teisès spragas. <...> Vaizdžiai kalbant, Konstitucija yra „skètis“, kuris uždengia viską - visą ordinarinę teisę, ir sukurtąją, ir tą, kuri dar bus sukurta, tačiau dèl kokių nors priežasčių nèra sukurta." ${ }^{13}$ Tai leidžia teigti elementarią tiesą, kad teisès sistema yra monocentriné, t. y. konstituciocentrinè, nes „yra vienas teisès sistemos teisinès galios centras - Konstitucija. Būtent jos turinys ir teisinė galia lemia visos teisès sistemos aktų hierarchijos pobūdị, vaizdingiau tariant,

8 Konstitucinio Teismo 2004 m. gegužès 25 d. nutarimo motyvuojamosios dalies II skyriaus 4 punktas. Ibid., 2004, Nr. 85-3094.

9 Konstitucinio Teismo 2004 m. gruodžio 13 d. nutarimo motyvuojamosios dalies II skyriaus 2 punktas. Ibid., 2006, Nr. 181-6708.

${ }^{10}$ Terminas ,ordinarinè teisé“, apibūdina visą teisinį reguliavimą, nustatytą žemesnès galios nei aukščiausiosios [konstitucinès] teisès aktais, jau senokai yra tapęs integralia jurisprudencinès Konstitucijos dalimi, pvz.: Konstitucinio Teismo $2006 \mathrm{~m}$. kovo $14 \mathrm{~d}$. nutarimo motyvuojamosios dalies II skyriaus 2 punktas. Valstybès žinios. 2006, Nr. 30-1050; Konstitucinio Teismo 2008 m. sausio $21 \mathrm{~d}$. nutarimo motyvuojamosios dalies II skyriaus 27 punktas. Ibid., 2008, Nr. 10-349; Konstitucinio Teismo $2010 \mathrm{~m}$. lapkričio 9 d. nutarimo motyvuojamosios dalies IV skyriaus 9.5 punktas. Ibid., 2010, Nr. 133-6800.

${ }^{11}$ Jarašiūnas, E. Konstitucija ir ịstatymas: kelios interpretavimo problemos. Konstitucijos aiškinimas ir tiesioginis taikymas, p. 241.

${ }^{12}$ Kūris, E. Europos Sajungos teise Lietuvos Respublikos Konstitucinio Teismo jurisprudencijoje: sambūvio algoritmo paieškos. Teise besikeičiančioje Europoje: Liber Amicorum Pranas Kūris. Ats. red. S. Katuoka. Vilnius: Mykolo Romerio universiteto Leidybos centras, 2008, p. 674.

${ }^{13}$ Kūris, E. Konstitucija kaip teise be spragų. Jurisprudencija. 2006, [t.] 12(90), p. $10-11$. 
konkretaus teisès akto gravitacini atstumą nuo Konstitucijos ar iki jos" ${ }^{\text {"14, }}$ todèl teisiškai niekaip nepaneigiama tai, kad „Konstitucijos viršenybė yra absoliuti“"15. Konstituciocentrinè teisès sistema susiformavo per ilgą laiką kaip tam tikras valstybès ir teisès raidos, in primis teismų veiklos (byla pionierè Marbury prieš Madisoną), rezultatas, visas teisinis gyvenimas sukasi aplink Konstituciją. Nors vadinamasis šiuolaikinis teisinis pliuralizmas (čia neturima galvoje istorinių tyrimų ${ }^{16}$ ar tyrimų, kuriuose nagrinejjami teisminès teisèkūros klausimai ${ }^{17}$ ) iš pirmo žvilgsnio galètų pasirodyti įtikinamas, nes, be valstybès teisès sistemos (Konstitucija nustato tarptautinès ir Europos Sąungos teisès vietą joje), yra ir, pavyzdžiui, kanonų ar apskritai religinès bei kitos teisès sistemos. Tačiau reikalas tas, kad „Konstitucija, kuri reguliuoja ir nustato, be to, yra aukščiausios teisinés galios aktas, nèra „teisès pliuralizmo“ pavyzdys"18 ir kad „pirmas klausimas, $\mathfrak{i}$ kurị reikia akademiškai ir profesiškai sąžiningai atsakyti, yra štai koks: kas legitimuoja ir legalizuoja šias koegzistuojančias teisès sistemas?"19 Konstitucija nedraudžia šių koegzistuojančių teisès sistemų, bet leidžia joms nacionalinèje erdvèje egzistuoti tik tiek, kiek jų veikimas neprieštarauja įstatymams, in primis Konstitucijai ir dorai (pvz., Konstitucijos 43 straipsnio 1, 6 dalys), todèl jų teisinė autonomija jokiu būdu nèra absoliuti (Konstitucijos 7 straipsnio 1 dalis). Šios konstitucinès nuostatos nereiškia, kad yra „<..> sukuriama visuomeninių

14 Ibid., p. 220.

15 Kūris, E. Konstitucinè justicija Lietuvoje: pirmasis dešimtmetis. Justitia. 2003, Nr. 3-4(45-46), p. 7.

${ }_{16}$ Pvz., Machovenko, J. Aristokratinei valstybei alternatyvių junginių teisès vaidmuo igyvendinant teisinès valstybès doktriną Lietuvos Didžiojoje Kunigaikštystèje. Jurisprudencija. 2010, [t.] 3(121), p. 39, 50.

17 E. Kūris apibendrina, kad pliuralistinèmis gali būti vadinamos tokios konkuruojančios „teisès sistemos, kuriose politinès valdžios neturi teisėkūros monopolio“ (Kūris, E. Teismo precedentas kaip teisès šaltinis Lietuvoje: oficiali konstitucinė doktrina, teisinio mąstymo stereotipai ir kontrargumentai. Jurisprudencija. 2009, [t.] 2(116), p. 132 .

18 Mesonis, G. Konstitucija monocentrineje teisès sistemoje. Konstitucinè jurisprudencija. 2008, Nr. 4(12), p. 224.

${ }^{19}$ Kūris, E. Konstitucijos dvasia. Jurisprudencija. 2002, [t.] 30(22), p. 18. 
santykių grupè, kuri viršytų konstitucinio reguliavimo ribas. Minètos Konstitucijos nuostatos dèl autonomijos nesukuria jokių teisinių posistemių, jokios teisinio reguliavimo entropijos ${ }^{\text {"20. }}$. Taigi konstituciocentrizmas pasireiškia kaip „visos teisès orientavimas ị Grundnorm “21 ir šiuo požiūriu negali susiklostyti jokia Doppelstaat situacija.

\section{Konstitucinio Teismo reikšmė atskleidžiant konstitucinių santykių turinị}

Oficialiai (teisiškai nekvestionuojant) tik „Konstitucinio Teismo aktuose yra aiškinamos Konstitucijos nuostatos ${ }^{22}$ - normos bei principai. Juose yra kuriama ir plètojama oficiali konstitucinė doktrina. Visi teisę kuriantys ir taikantys subjektai, įskaitant ir teismus, taikydami Konstituciją, privalo paisyti oficialios konstitucinès doktrinos, jie negali aiškinti Konstitucijos nuostatu kitaip, nei savo aktuose yra išaiškinęs Konstitucinis Teismas [kursyvas autoriaus - T. B. pastaba] "23. Konstitucija, kaip teisinio reguliavimo pilnatvè, pasak E. Jarašiūno, iš tikrųjų yra tobula teis $\dot{e}^{24}$,

${ }^{20}$ Mesonis, G. Konstitucija monocentrinèje teisès sistemoje. Konstitucine jurisprudencija. 2008, Nr. 4(12), p. 225. Taip pat: Mesonis, G. Konstitucijos interpretavimo metodologiniai pagrindai: monografija. Vilnius: VỊ Registrų centras, 2010, p. 37. Plačiau: Mesonis, G. Kai kurie konstituciniai valstybès ir bažnyčios santykių aspektai. Konstitucine jurisprudencija. 2008, Nr. 2(10), p. 121-125.

${ }^{21}$ Kūris, E. Konstitucija kaip teisè be spragų. Jurisprudencija. 2006, [t.] 12(90), p. 8.

${ }^{22}$ Pirmą kartą ši išimtinè teisè paminèta Konstitucinio Teismo 2003 m. gegužès $30 \mathrm{~d}$. nutarimo motyvuojamosios dalies I skyriaus 11.2 punkte. Valstybès žinios. 2003, Nr. 53-2361.

${ }^{23}$ Konstitucinio Teismo 2005 m. rugsèjo 20 d. sprendimo motyvuojamosios dalies III skyriaus 4 punktas. Valstybès žinios. 2006, Nr. 113-4132.

${ }^{24}$ Iš tiesų Konstitucijos apibūdinimas labai gražus, tačiau Konstitucijos (ir jurisprudencinès) tobulumas išryškejja ją lyginant su ordinarine teise, bet ne savaime. Konstitucija nelyginama su visai kitos substancijos tobulumu, pvz., L. van Beethoveno ar W. A. Mozarto muzika. Todèl, suprantama, Konstitucija yra tobula savo reikšme tautos ir valstybės gyvenime ir šiuo atžvilgiu ji yra svarbesnè už kitą žmogiškają kūrybą, su viena išlyga - tik dèl Konstitucinio Teismo lygiai reikšmingos teisminès kūrybos Konstitucija nelieka statiška, deklaratyvi. Ji yra gyvoji konstitucija. Todèl visur pasaulyje konstitucinės justicijos institucijos neišvengia ir kritikos. Net Vokietijoje, 
nes būtent „per konstitucinę jurisprudenciją igyja teisès par excellence

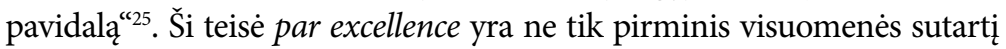
išreiškiantis konstitucinis steigiamosios valdžios dokumentas, bet ir nuolat besivystanti bei atsinaujinanti gyvoji konstitucija kaip Konstitucijos „pirmapradžio teksto“ ir oficialiosios konstitucinès doktrinos vienové2 ${ }^{26}$, kaip Konstitucijos raidès (Konstitucijos nuostatų lingvistinès formos arba expréssis verbis) ir Konstitucijos dvasios (tų vertybių ir siekių, kuriuos tauta Konstitucijoje įtvirtino pasirinkusi tam tikrą jos nuostatų tekstinę formą, kalbinę išraišką, arba konstitucinio reguliavimo visumos prasmès) vienovè $^{27}$. Šią veikiančios, evoliucionuojančios gyvosios konstitucijos idèją tiksliai atspindi jurisprudencinés konstitucijos kategorija ${ }^{28}$, nes „Konstitucija yra tai, ka konstatuoja Konstitucinis Teismas“, arba, kitaip tariant, „Konstitucijos realiai yra tiek, kiek yra išaiškinęs Konstitucinis Teismas ${ }^{\text {“29. }}$

nors Karlsrūhès teismas yra kone labiausiai visuomenès gerbiama valstybès valdžios institucija, taip pat neretai papriekaištaujama dèl per daug ,Justizstaat “ valstybèje.

25 Jarašiūnas, E. Aukščiausioji ir ordinarinè teisè: požiūrio ì Konstituciją pokyčiai. Jurisprudencija. 2002, [t.] 33(25), p. 36.

${ }^{26}$ Kūris, E. Konstitucijos dvasia. Jurisprudencija. 2002, [t.] 30(22), p. 22; Kūris, E. Konstitucinė justicija Lietuvoje: pirmasis dešimtmetis. Justitia. 2003, Nr. 3-4 (45-46), p. 3.

${ }^{27}$ Konstitucinio Teismo $2004 \mathrm{~m}$. gegužès 25 d. nutarimo motyvuojamosios dalies II skyriaus 4 punktas. Valstybès žinios. 2004, Nr. 85-3094.

${ }_{28}$ Jarašiūnas, E. Jurisprudencinė konstitucija. Jurisprudencija. 2006, [t.] 12(90), p. 24,32 .

${ }^{29}$ Kūris, E. Konstitucinė justicija Lietuvoje: pirmasis dešimtmetis. Justitia. 2003, Nr. 3-4(45-46), p. 5. Jau LDK teisèjas Petras Roizijus dedikaciniame laiške Lenkijos karaliui Žygimantui Augustui rašè: „Magistratas yra naudingesnis už įstatymų leideją. Tačiau manau, kad tie žmonès, kurie sprendžia bylas taip, kaip nustatyta ịstatymų, pralenkia ir gerokai pranoksta teisès normų kūrèjus. Sakykit, ką gi daugiau teikia ịstatymų leidèjas valstybei (nors tai ir labai didelis dalykas), be galimybès piliečiams gerai ir laimingai gyventi, būti saugiems su savo vaikais ir turtais? O magistratas ir kiekvienas tas, kuris vadovauja jurisdikcijai, daug labiau pasitarnauja, kad jie gerai gyventų ir kad leistų amžių nedejuodami, apsaugoti, nepatirdami jokių skriaudų, nebijodami. <..> Tegul įstatymas bus geras, tegul bus teisingas, tegul bus šventas, tegul bus nepriklausomas nuo visų suinteresuotųu, pagaliau tegul bus atsiųstas iš dangaus, bet jei magistratas jo nepalaikys griežtumu ir valdžia, jis bus tik žmonių pajuokai ir patyčioms." Roizijus, P. Lietuvos sprendimai, 1563. Sudarè 


\section{Konstituciniai santykiai ar (ir) konstituciniai teisiniai santykiai?}

Šiame straipsnyje pateiktoje konstitucinès teisès apibrèžtyje nėra expréssis verbis inkorporuota sąvoka „santykiai“, t. y. aukščiausioji teisẻ nebeapibréžiama per reguliuojamų visuomeninių santykių prizmę. „Konstituciniai teisiniai santykiai“ tradicinèje dogmatikoje būdavo apibrèžiami kaip „konstitucinès teisès normų sureguliuoti visuomeniniai santykiai“, tiesa, „svarbiausi“ ${ }^{\text {“30, }}$, stengiantis kuo labiau detalizuoti tokių santykių sritị (objektą arba dalyką) ${ }^{31}$, kuri iš esmès sutapo su atitinkamai suprantamos konstitucinès teisès reguliavimo objektu, visiškai neklausiant, „kodèl vieni santykiai laikytini „svarbiausiais“, o kiti - lyg ir ne tokiais svarbiais“32. Tačiau iš anksčiau pateikto konstitucinès teisès, kaip aukščiausiosios teisès, apibrèžimo sistemiškai ir logiškai darytina išvada, kad konstitucinè teisė „išvis neturi teisès šakoms büdingo atskiro reguliavimo dalyko, turinio atžvilgiu jos reguliavimo dalykas yra visa apimantis ir interpretuotinas holistiškai"33.

V. Andriulis; vertė D. Dilytė. Vilnius: Teisinès informacijos centras, 2007, p. 4.

${ }^{30}$ Jarašiūnas, E. Konstitucinè teisè - nacionalinès teisès sistemos branduolys ir teisès sistemą integruojanti teisès sritis. Lietuvos konstituciné teisé. Vadovèlio parengimo koordinatorius E. Jarašiūnas. Vilnius: Lietuvos teisès universitetas, 2001, p. 49, 21,33 .

31 Ibid., p. 51-53. Arba ją kuo labiau apibendrinti: „Konstitucinė teisè kultūringose šalyse yra pagrindinè viešosios teisès dalis. Be jos neįmanomos kitos viešosios teisès sritys. Taip pat be jos neịmanoma privatinè teisè, kada ji pasirodo rašytos teisès forma. Konstitucinė teisė turi trigubą objektą. Ji nustato: 1) valstybès formą; 2) valdžios ir jos organų formą; 3) valstybès teisių ribas." Esmein, A. Konstitucinès teisès principai (prancūzų ir palyginamieji). T. 1, d. 1. Kaunas: Teisininkų draugijos leidinys, 1932, p. 1.

${ }^{32}$ Kūris, E. Konstitucinè teisè kaip jurisprudencine teisé: konstitucine justicija ir konstitucinés teisès paradigmos transformacija Lietuvoje: habilitacijos procedūrai teikiamų mokslo darbų apžvalga: socialiniai mokslai, teisė (01S). Vilnius: [Vilniaus universiteto leidykla], 2008, p. 17.

${ }^{33}$ Ibid., p. 9, 25. 
Konstitucinis Teismas savo jurisprudencijoje nèra pateikęs nei konstituciniu santykių, nei konstituciniu teisiniu santykių ${ }^{34}$ sampratos (pastaroji sąvoka dažniau vartojama teisès mokslininkų darbuose). Svarstant minètas sąvokas aptartos konstitucinès teisès paradigmos kontekste, logiškai (nors galbūt teisiškai ir nepagrịstai) kyla klausimas, ar terminas „konstituciniai santykiai“ yra pakankamas ir ar terminas „konstituciniai teisiniai santykiai“ nèra perteklinis. Kelti tokị klausimą paakina pati konstitucinès teisès samprata, nes jeigu konstitucinè teisè yra ius supremum, kuri nuo ordinarinès teisès skiriasi teisès aukščio dimensija, jeigu ji aprèpia bet kurị ordinarinio reguliavimo dalyką, tai kaipgi iš aukščiausiosios teisès kylantys santykiai gali nebūti teisiniai?

Kiekvienas žmogus nuo pat gimimo iki mirties yra konstitucinės teisès reglamentuojamų santykių dalyvis, ir ne tik žmogus, bet ir valstybẻ bei visi kiti asmenys yra nuolatiniai konstitucinių santykių dalyviai. Aukščiausioji [konstitucinè] teisè negali būti neteisè, kaip ir konstituciniai santykiai negali būti neteisiniai, ir visai nesvarbu, kad kasdieninio savo konstitucinių teisiu igyvendinimo, pavyzdžiui, turèti savo ịsitikinimus (Konstitucijos 25 straipsnio 1 dalis), arba nevaržomo naudojimosi, pavyzdžiui, minties, tikejjimo ir sąžinès laisve (Konstitucijos 26 straipsnio 1 dalis), nekonstatuojame tam tikra teisine forma. Šiuo požiūriu terminas „konstituciniai [plius] teisiniai santykiai“ atrodo perteklinis. Pavyzdžiui, jokios konstitucinès ar kitos nuostatos nereguliuoja pagal Konstitucijos 43 straipsnio 1 dalị valstybès pripažintų tradicinių bažnyčių ir kitų religinių organizacijų atstovų dalyvavimo iškilminguose Seimo posėdžiuose valstybinių švenčių ar kitomis progomis; nèra jokios nei implicitinès, nei eksplicitinès teisinès nuostatos dèl Lietuvos Respublikos Prezidento inauguracijos iškilmių pratęsimo vienos iš valstybès pripažintų tradicinių bažnyčių pagrindinèje šventovèje; nèra nieko pasakyta dèl dažniausiai tos vienos (bet anaiptol ne visada tik jos) bažnyčios dvasininkų atliekamo valstybės valdžios ar savivaldybių institucijų, valstybės ir

${ }^{34}$ Pvz., Konstitucinio Teismo $2006 \mathrm{~m}$. kovo 28 d. nutarimo motyvuojamosios dalies II skyriaus 31 punktas. Valstybès žinios. 2006, Nr. 36-1292. 
savivaldybių mokymo ir auklējimo įstaigų patalpų šventinimo ir t. t. Tačiau tai nereiškia, kad minèti santykiai turi konstitucinès patikros imunitetą, yra „išimti“ iš Konstitucijos ir kad Konstitucija tokių santykių nereglamentuoja. Pakaktų vien konstitucinès justicijos ar administracinés justicijos (pvz., dẻl savivaldybių tarybų arba kitų vietos ar centrinių institucijų panašių aktų konstitucingumo) bylos kontekste pabandyti išskaityti iš Konstitucijos tokių santykių reguliavimo konstitucinius pamatus, pavyzdžiui, atskleidžiant vis naujus konstitucinio valstybès pasaulèžiūrinio ir religinio neutralumo principo arba kurio nors kito eksplicitinio ar implicitinio konstitucinio principo ar konstitucinès normos fragmentus (tai nereikètų suprasti kaip tendencingo nusistatymo nurodytų principų turinị interpretuoti griežčiau, nes čia iš viso nesiryžtama prognozuoti, kokia oficialiosios doktrinos plètojimo linkme Konstitucinis Teismas pasuktų). Šiuo požiūriu sąvoka „konstituciniai santykiai“ laikytina savaime pakankama iš konstitucinès teisès kylantiems santykiams apibūdinti.

Kita vertus, kaip jau minèta, pats Konstitucinis Teismas yra pavartojęs sąvoką „konstituciniai teisiniai santykiai“, be to, kitame kontekste neretai abi sąvokos - „konstitucinis“ ir „teisinis“ - vartojamos greta, kaip antai „konstitucinis teisinis reguliavimas“, tiesa, nepakankamai nuosekliai, kadangi tame pačiame kontekste šalia vartojama tiesiog sąvoka „konstitu-

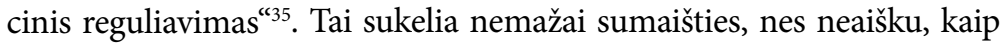
konstitucinè (teisès par excellence) nuostata gali būti neteisinè, o jeigu visos konstitucinès nuostatos yra teisinès, tai kam reikalingas papildomas epitetas ir ar nederètų atskiriant konstitucinį reguliavimą nuo ordinarinio

35 Pabrėžtina, kad atskleisti įvairių konstitucinių nuostatų tarpusavio sąsajų, jų turinio santykio, konstitucinių vertybių pusiausvyros, konstitucinio teisinio reguliavimo [kursyvas mano - T. B. pastaba], kaip vieningos visumos, esmès būtų neįmanoma, jeigu būtų ignoruojami konstitucinio reguliavimo [kursyvas mano - T. B. pastaba] tikslai, apimantys, inter alia, ir tuos tikslus, kuriais yra grindžiamos kiekvienos aiškinamos konstitucinès nuostatos funkcijos, paskirtis visuminio konstitucinio reguliavimo [kursyvas mano - T. B. pastaba] atžvilgiu. (Konstitucinio Teismo $2004 \mathrm{~m}$. liepos $1 \mathrm{~d}$. nutarimo motyvuojamosios dalies II skyriaus 9 punktas. Ibid., 2004, Nr. 105-3894). 
būtent taip aiškiai šias sąvokas ir vartoti. Be kita ko, tai dera ir žvelgiant iš lingvistinių pozicijų, nes lietuvių kalboje, kitaip nei, pavyzdžiui, vokiečių kalboje, kurioje sąvoka „verfassungsrechtlich“ verčiama kaip „konstitucinis teisinis“, puikiausiai galime išsiversti su šiomis sąvokomis.

Straipsnyje jokiu būdu nepretenduojama pateikti vieninteles teisingos nuomonès. Greičiau esame linkę manyti, kad sąvoka „konstitucinis teisinis" labiau išplečia reguliavimo lauką ir tiesiogiai apima ordinarinę teisę, todèl yra susijusi tiek su konstitucine, tiek su valstybine teise $e^{36}$. Jau esame pateikę klasikinị konstituciniu teisiniu santykiu apibrěžimą, kuris čia nekritikuojamas kaip blogas. Jis tiesiog visiškai atitiko vyraujančią konstitucinès teisès sampratą ir teisès teoriją, pagal kurią konstituciniai teisiniai santykiai atsiranda, pasikeičia ir baigiasi igyvendinant konstitucinès teisès normas; klasikinèje definicijoje netgi išvardijami konstitucinių teisinių santykių subjektai ir apibrėžiamos šių santykių objekto sritys - socialinès vertybès, o šių santykių turinį sudaro jų dalyvių subjektinès teisès ir teisinès pareigos ${ }^{37}$. Buvo teigiama, kad „konstitucinių teisinių santykių sriti apibrěžia konstitucinès teisès reguliavimo objektas“"38, kurio apibrèžimo galimybès šiame straipsnyje atsisakyta. Netgi šiuo metu naujausiame lietuviškame konstitucinès teisès vadovèlyje yra būtent konstitucinių teisiniu santykių definicija ir jos apibūdinimas: „Konstituciniai teisiniai santykiai - tai konstitucinès teisès normomis sureguliuoti visuomeniniai santykiai, kurių dalyviai

36 Valstybinè teise - tai ordinarinès teisès šaka, reguliuojanti pilietybès, valdžių sandaros ir pan. santykius įstatymais ir poịstatyminiais teisès aktais, taigi ne konstitucinès teisès lygmeniu. Ibid., p. 11, 26. Autoritetingiausiame Šveicarijoje valstybinès teisès vadovėlyje (Häfelin, U., Haller, W. Schweizerisches Bundesstaatsrecht. Die neue Bundesverfassung. 6., stark überarbeitete Auflage. Zürich, Basel, Genf: Schulthess Juristische Medien AG, 2005).

37 Jarašiūnas, E. Konstitucinè teisè - nacionalinès teisès sistemos branduolys ir teisès sistemą integruojanti teisès sritis. Lietuvos konstitucine teisé... 2001, p. 49-52. Teigiama, kad dvi pagrindinès santykių sritys yra reguliuojamos Konstitucijos: pirmoji - ,asmens statusas, žmogaus ir piliečio teisių ir laisvių sritis“, antroji „,viešosios valdžios organizacijos ir funkcionavimo santykiai“.

38 Ibid., p. 52. 
turi atitinkamas subjektines teises ir teisines pareigas. Šie santykiai yra viena iš teisinių santykių rūšių. Konstituciniai teisiniai santykiai turi bendrus visiems teisiniams santykiams požymius ir tik šiems santykiams būdingus ypatumus." ${ }^{39}$ Tačiau toliau šiame vadovėlyje yra nurodoma daugiau minėtų požymių nei ypatumų. Šie, tiesą sakant, taip ir liko neatskleisti, jeigu palygintume, pavyzdžiui, su lietuvišku teisès teorijos vadovèliu, kuriame pateikiama ir analizuojama bendroji teisiniu santykių samprata: „Teisiniai santykiai - tai realioje tikroveje pasireiškiantys tarpasmeniniai ryšiai, kurie atsiranda šių santykių dalyviams turint tam tikrą teisinę savybę - teisinị subjektiškumą - teisès principų ir / ar normų pagrindu dèl tam tikrų objektyvių gèrių (vertybių) - interesų; tai santykiai, kurių dalyviai turi subjektines teises ir teisines pareigas ir kurie, esant būtinybei, gali būti užtikrinami valstybès prievartos priemonèmis. " ${ }^{40}$ Lyginant abu vadovèlius iš karto galima pastebèti, kad juose panašiai vardijami tiek konstitucinių, tiek apskritai teisinių santykių subjektai, objektai, turinys, jų atsiradimo, pasikeitimo ir pabaigos pagrindai. Daroma prielaida, kad konstituciniai teisiniai santykiai yra viena iš teisinių santykių (atskiriant juos pagal teisès sritis), kurie sureguliuoti atitinkamos teisès srities (šiuo atveju - konstitucinès) teisés principais ir normomis ${ }^{41}$, rūšių ${ }^{42}$. Tačiau iš to visiškai neaišku, kas yra

39 Žiobienè, E. Konstitucinès teisès samprata. Lietuvos konstitucine teisé: vadovèlis: Liber Amicorum Juozui Žiliui. Red. kolegija: E. Jarašiūnas, et al. Vilnius: Mykolo Romerio universitetas, 2012, p. 84.

${ }^{40}$ Spruogis, E. Teisiniai santykiai. Teisès teorijos ịvadas: vadovèlis: Liber amicorum prof. dr. Egidijui Jarašiūnui - 60. 2-asis pataisytas ir papildytas leidimas. Moksliniai redaktoriai: L. Baublys, E. Spruogis. Vilnius: Mes, 2012, p. 429.

${ }^{41}$ Minètame konstitucinès teisès vadovélyje konstitucinių santykių kilmè siejama vien su konstitucinės teisės normų igyvendinimu (,,konstituciniai teisiniai santykiai kyla igyvendinant konstitucinès teisès normas"; ,konstitucinès teisès normos suteikia galimybę ịgyvendinti konstitucines teises ir vykdyti konstitucines pareigas")! Maža to, stengiamasi išvardyti sritis, kurias šios normos nustato: ,valstybès organizaciją, viešosios valdžios organizavimą ir igyvendinimą, taip pat asmens ir valstybès santykių pagrindus bei kita“. Žiobienè, E. Op. cit., p. 84. Todèl nebeaišku, kaip tarp gausybès teisiniu santykiu atpažinti konstitucinius santykius.

${ }^{42}$ Spruogis, E. Teisès igyvendinimas (realizavimas). Ibid., p. 458. 
konstitucinès teisès principų ir normų šaltiniai, iš kurių galètume tuos principus ir normas identifikuoti, pavyzdžiui, kokius santykius reguliuoja Lietuvos Respublikos pilietybès įstatymas.

Nors konstituciniu santykiu pagrindas nèra ordinarinè teisè, vis dèlto teisinio reguliavimo aukščio dimensijos (reguliavimo objekto požiūriu) kai kuriais atvejais neišvengiamai susipina, pavyzdžiui, kai kalbame apie pilietybės institutą, kuris apima tiek konstitucinę, tiek ordinarinę teisę. Tokiu atveju greičiausiai galime kalbėti apie vadinamosios valstybinès teisès sritị. Vadovaudamiesi konstitucinès teisès teorijoje atskleista konstitucinès ir valstybinès teisès skirtimi konstatuojame, kad valstybine teise vadintume visa (konstitucinę ir ordinarinę) valstybès nustatytą teisinę tvarką. Tačiau konstitucine teise vadintume vien [aukščiausio] konstitucinio lygmens teisinès tvarkos sistemą, reguliuojančią konstitucinius santykius ir apimančią pagrindinių teisių sritị.

\section{Konstituciniai santykiai yra determinuojami konstitucinių vertybių sistemos}

Atrodo nekvestionuotina, kad teisinių santykių subjektas, žmogus (kantiškasis tikslas savyje), neturètų būti traktuojamas kaip teisinių santykių objektas, nors mąstant apie atskiras priverstinio gydymo, užgrobto keleivinio lèktuvo sunaikinimo valstybès valdžios sprendimu ar pan. situacijas tai gali ir nepasirodyti taip jau akivaizdu. O gal reikètų kelti klausimą, ar paskiros žmogaus teisès ir laisvès, kaip konstitucinès vertybès, gali būti traktuojamos kaip konstitucinių santykių objektas ${ }^{43}$ ?

${ }^{43}$ Antai Vokietijos Federalinis Konstitucinis Teismas, kurio jurisprudencijoje labiau atpažistama tam tikros konstituciniu vertybiu tvarkos doktrina, spręsdamas provokuojantị konstitucinį skundą dèl Oro saugumo isstatymo nuostatu atitikties Konstitucijai, t. y. ar neprieštarauja Pagrindiniam ịstatymui minèto ịstatymo nuostatos dèl karinių pajègų dalyvavimo malšinant gamtos ir kitas katastrofas, inter alia, ar galètų karinès pajègos, esant itin grèsmingoms situacijoms, numušti keleivini lèktuvą, kai kitiems gresia pavojus, primenantis $2001 \mathrm{~m}$. rugsejo $11 \mathrm{~d}$. ịvykius JAV, vis dèlto įstengè ,išlįsti per adatos skylutę“. Apibendrintai galima 
Kai kurie autoriai $\mathfrak{i}$ tai atsako teigiamai: „Konstituciniu teisiniu santykiu objektas - socialinès vertybès. Jos yra įtvirtintos Konstitucijoje ir konstitucineje jurisprudencijoje. Tai tokios vertybės kaip prigimtinès žmogaus teisès ir laisvès. “44 Kitur pačios „asmeninio pobūdžio vertybès“, tokios kaip gyvybe், laisvè, orumas ir kt., yra laikomos teisinių santykių objektais, o jau konkrečios subjektinès teisès, pavyzdžiui, teisė $\mathfrak{i}$ gyvybę, teisè ị laisvę, teisè ị orumą (taip pat teisinès pareigos ir veikos), sudaro teisinių santykių turinị $\mathfrak{t}^{45}$. Kuris požiūris teisingas?

Atsakymas ị ši klausimą tiesiogiai priklauso ne tik nuo konstitucinès teisès sampratos, bet pirmiausia nuo žmogaus teisių sampratos. Šiame straipsnyje nekeliame sau tikslo detaliai aptarti žmogaus teisių ir laisvių koncepcijų, juolab kad šiuo požiūriu tai tarsi jau išsemta tema. Pasinaudosime straipsniu, kuriame išryškinami dviejų Vakaruose vyraujančių požiūrių ì žmogaus teises skirtumai. Gediminas Mesonis

pasakyti, kad H. J. Papiero pirmininkaujamas Pirmasis senatas atsilaikè briliantine argumentacija apgindamas Konstituciją (t. y. tai, kas joje yra, o ne tai, ko buvo pageidauta), nuosekliai atkartodamas pagrindines ankstesnès jurisprudencijos nuostatas dẻl žmogaus orumo, būtent: ,žmogaus gyvybė yra vitalinè žmogaus orumo, kaip fundamentalaus konstitucinio principo ir aukščiausios konstitucinès vertybès, bazé"; ,valstybè expressis verbis yra ịpareigota gerbti ir saugoti žmogaus orumą“, dèl to „valstybė negali traktuoti žmogaus vien kaip objekto“; ,žmogaus gyvybė ir žmogaus orumas, kad ir kokia būtų žmogaus psichinė egzistencija, yra vienodai konstituciškai saugomos" ir t. t., todèl karinių pajėgų veiksmai, jeigu jie nukreipti ị lèktuve esančius nekaltus žmones, nesuderinami su minètomis aukščiausiomis konstitucinèmis vertybėmis (Urteil des Ersten Senats des Deutschen Bundesverfassungsgerichts vom 15. Februar 2006 (BVerfGE 115, $118<151$ ff.> Luftsicherheitsgesetz) 1 BvR 357/05). Galbūt galima oponuoti A. Barako argumentu, kad „teisių sąvadas neturi tapti savižudybès receptu“ (Barak, A. Teismo diskrecijos prigimtis ir jos reikšmė vykdant teisingumą. Vertė R. Naujokaitis. Justitia. 2005, Nr. 3(57), p. 27), tačiau argi Federalinis Konstitucinis Teismas galejo nuspręsti kitaip?! Net atskirujų nuomonių nebuvo, nes pamatinès vertybès ,nèra visuomenès apklausų rezultatas. <..> Jos atspindi istoriją, o ne isteriją.“"(Ibid., p. 26).

44 Žiobienè, E. Op cit., p. 85.

45 Spruogis, E. Teisiniai santykiai. Teisès teorijos juvadas: vadovèlis: Liber amicorum prof. dr. Egidijui Jarašiūnui - 60. 2-asis pataisytas ir papildytas leidimas. Moksliniai redaktoriai: L. Baublys, E. Spruogis. Vilnius: Mes, 2012, p. $455-459$. 
šiuos skirtumus išryškina analizuodamas valstybės vẻliavos teisinị statusą aktualiame nacionaliniame ir istoriniame Vakarų pasaulio kontekste $^{46}$. Straipsnyje puikiai atskleista, pasak autoriaus, „žmogaus teisių suvokimo dichotomija: vienaskaita prieš daugiskaitą", arba kitaip - individualistinis ir traibalistinis požiūris į žmogaus teises ${ }^{47}$. Viename jų „anglų ir amerikiečių (liberaliojoje) teorijoje žmogaus teisių ir laisvių sampratos šerdis yra ta, kad čia, sprendžiant žmogaus teisių ir laisvių bei pareigu pusiausvyros problemas, žmogus yra suvokiamas kaip subjektas, gebantis ir turintis galimybę asmeniškai igyvendinti savo teises“; kiekvienas „žmogus turi moralines teises, ginančias ji nuo valstybès“, o tai reiškia, kad yra asmens teisių prioritetas prieš valstybę ${ }^{48}$. Pagal liberaliąją doktriną asmens teisių ribojimas galimas tik tada, kai konkreti teisè ar laisvè „kertasi su kito konkretaus žmogaus teise ar laisve“, o pagal traibalistinę - su asmenų grupès teisèmis ir laisvėmis ${ }^{49}$.

Iš tikrųjų, matyt, vertinant šiuos abu požiūrius ì pagrindines tei$\operatorname{ses}^{50}$ reikètų ieškoti tam tikro aurea mediocritas. Šio straipsnio autoriui iš karto prisimena profesoriaus R. Alexy valstybinès teisès II (pagrindinių teisių) paskaitos Kylio universitete. Iš R. Alexy paskaitų ịstrigo kelios pagrindinių teisių definicijos. Iš tikrųjų, jau minètas liberalusis požiūris ị žmogaus teises išreiškiamas ne formaliuoju, bet materialiuoju pagrindiniu teisių apibréžimu, kuriuo būtent ir nurodoma, kad pagrindinès teisès yra visų pirma liberaliosios pagrindinès teisès: laisvé, gyvybe், nuosavybė. Jos yra tokios pagrindinès teisès, kurias (kaip ịtvirtinta Vokietijos Pagrindinio ịstatymo 1 straipsnio 2 dalyje) „tauta

${ }^{46}$ Mesonis, G. Vèliava - Flag - Drapeau, arba ir vèl apie žmogaus teises. Teisé. 2012, Nr. 83, p. 18-36.

${ }^{47}$ Ibid., p. 28-33.

48 Ibid., p. 29.

${ }^{49}$ Ibid., p. 31, 33.

${ }^{50}$ Vokietijos Federacinès Respublikos Pagrindinio įstatymo 19 straipsnio 3 dalies nuostata nusako pagrindinių teisių galiojimo sriti - tai yra tokios teisès, kurios galioja ne tik fiziniams, bet ir juridiniams asmenims, jeigu tik pagal savo esmę jiems gali būti pritaikomos (Grundgesetz für die Bundesrepublik Deutschland vom 23. Mai 1949. BGBl. S. 1). Tai visuotinai pripažinta kaip aksioma. 
išpažìsta kaip nepažeidžiamas ir neatimamas, kaip kiekvienos žmonių bendruomenès, taikos ir teisingumo pasaulyje pagrindą“. Taigi ne mažiau reikšminga yra pačioje žmonių bendruomenejje, o ne tik vyraujančioje mokslinejje doktrinoje pagrindinių teisių samprata, kad jeigu kiekvienas yra įsisąmoninęs žmogaus teisių primatą prieš valstybę, tokios visuomenès kultūrinė ir teisinẻ branda pasireikš būtent pripažįstant individo teisių viršenybę prieš bendruomenines teises. Tačiau taip jokiu būdu neeliminuojamas pačios žmonių bendruomenès sukurtos valstybès vaidmuo pagrindinių teisių garantavimo srityje, nes valstybè yra laisvés erdvé paskiram asmeniui gyventi, veikti ir kurti. Būtent todèl pagal procedūrinę pagrindiniu teisiu definiciją skelbiama, kad be pagrindinių teisių neįmanoma demokratija, o pagrindinès teisès yra tokios svarbios, kad priimti sprendimą dèl jų suteikimo ar nesuteikimo negali būti patikèta paprastai parlamentinei daugumai.

Ar priimti tokị sprendimą gali būti patikèta tautai arba, kitaip tariant, pilietinei bendruomenei? Konstituciškai - taip. Nes be to negalima demokratija, tačiau demokratijos lygis priklauso nuo jau minèto asmens pagrindinių teisių primato įsisąmoninimo lygio. Juk Konstitucija, kurioje ịtvirtinta liberali asmens pagrindinių teisių koncepcija, yra tautos aktas (jei ne pagal prièmimo būdą, tai mažų mažiausiai pagal turinị). Viena vertus, tauta yra Konstitucijos kūrẻja, tačiau, kita vertus, Konstitucija yra asmeni ginantis antimažoritarinis aktas. Žmogaus teisès in corpore yra integrali žmogaus prigimties esmès dalis. Jos priklauso asmeniui, kad ir kokioje valstybejje jis gyventų, ir šiuo požiūriu gali būti apibūdinamos kaip ikivalstybinès arba viršpozityvios teisès. Bet juk negalime pažinti to, ko negalime įvardyti. Taigi konkrečių žmogaus teisių atpažinimas taip pat yra ne vien teisės doktrinos reikalas, bet ir žmonių bendruomenès kultūrinès (plačiąja prasme) raidos rezultatas (čia jokiu būdu neteigiama vien pažanga), nuolatinio kovos dèl konstitucionalizmo idejų igyvendinimo proceso vaisius. Todèl žmogaus teisių raida yra ne statiškas, bet dinamiškas procesas, tačiau ne stichinis. Dinamiškas ne dèl pačios žmogaus prigimties, iš kurios kildinamos žmogaus teisès, 
dinamiškumo, o dèl dinamiškumo aplinkinio pasaulio, kuriame žmogus turi taikiai [su]gyventi su kitais ir su ta pačia kintančia aplinka. Būtent šiame Vakarų kultūriniame procese ir išaukštinamos žmogaus teisès, joms teikiamas prioritetas prieš valstybę, prieš pačią bendruomenę, atitinkamai stengiamasi užtikrinti ir jų apsaugą. „Žmogaus teisès kartais net pavadinamos „naująja mūsų dienų religija“. Vakarų teisinejje civilizacijoje pripažįstama, kad „individas turi senesnių ir aukštesnių teisių už valstybès teises ir kad dèl to valstybė turi jas gerbti. "“51

Taigi grižzdami prie pirmiau užduoto klausimo, ar žmogaus teisès gali būti konstitucinių santykių objektas, negalime išleisti iš akių visuotinai pripažįstamo žmogaus teisių prigimtinio pobūdžio, t. y. to, kad žmogaus teisès, kaip subjektyvios, yra viršpozityvios. Šios teisiškai atpažintos ir nuolatiniame jų jurisprudencinio atpažinimo procese esančios teisès yra pozityviu pavidalu ịtraukiamos i pagrindinių teisių katalogą, kitaip tariant, jos iggauna teisiškai atrastą materialią išraišką arba tampa konstituciniais gèriais. Ieškant konkuruojančių konstitucinių gèrių juridinès pusiausvyros gali būti atpažinti nauji, iki tol buvę nepažinūs (implicitiniai), konstituciniai gèriai, t. y. naujos žmogaus teisès. Taigi kalbame ne tik apie Konstitucijoje ${ }^{52}$ įtvirtintas

${ }^{51}$ Jarašiūnas, E. Konstitucinè kontrolè: keletas minčių apie žmogaus teisių apsaugos matmenị. Konstituciné jurisprudencija. 2009, Nr. 4(16), p. 162.

52 Buvęs Vokietijos Federalinio Konstitucinio Teismo teisèjas K. Hesse (1919-2005) savo darbuose neatitrūko nuo šio teismo jurisprudencijos, kai apibendrino, kad konstitucijos kūrejjas turi konstituoti tokią valstybès bütį (Staatswesen), kuri yra „neutrali pasaulèžiūriniu, bet ne vertybiniu požiūriu“. Federalinis Konstitucinis Teismas pabrèże ,ne formalios, bet turiningos [t. y. substantyvinès] [intarpas mano T. B. pastaba] konstitucijos sampratą; konstitucija apibrèžiama kaip materiali visuma. Konstitucijos turinys $\langle\ldots>$ apibrěžiamas kaip fundamentalios, pirmiau pozityviosios teisinès tvarkos esančios vertybès, kurios, konstitucijos kūrèjo sprendimu, yra sujungtos ị vieną „vertybių tvarką“, kurią sudaro liberalios reprezentacinès parlamentinès demokratijos, liberalios teisinès valstybès ir federacinès valstybès tradicijos perémimas, pridedant ir naujų, pirmiausia socialinès valstybės, principų.“ Hesse, K. Grundzüge des Verfassungsrechts der Bundesrepublik Deutschland. Neudruck der 20. Auflage. Heidelberg: C. F. Müller Verlag, 1999, S. 4. 
svarbiausias valstybinès bendruomenès - pilietinès tautos vertybes, bet ir apie šių konstituciniu vertybiu pusiausvyrą (Konstitucinio Teismo $2004 \mathrm{~m}$. gegužès $25 \mathrm{~d}$. nutarimo motyvuojamosios dalies II skyriaus 1 ir 4 punktai ir kt.). Ši pusiausvyra tiesiogiai siejasi su santykio (Verhältnis) sąvoka ir išreiškia proporcingumą (Verhältnismäßigkeit), kuris, kaip „konstitucinio rango principas, išvedamas iš teisinès valstybès principo ir iš pačios esmès pagrindinių teisių, kurios, kaip piliečio laisvès pretenzijos valstybei (des allgemeinen Freiheitsanspruchs des Bürgers gegenüber dem Staat) išraiška, viešosios valdžios gali būti ribojamos tik tiek, kiek yra būtina viešajam interesui apsaugoti ${ }^{\text {“53. Tai }}$ reiškia, kad pagrindinès teisès, kaip minèta, visų pirma (pirmiau nei status positivus ar status activus) yra asmens status negativus teisès asmens erdvè, laisva nuo valstybès kišimosi, teisès filosofijoje dar vadinamos laisve $n u o^{54}$ arba kantiškosios analitikos sąvoka „die Freiheit der Willkür“ (savivales, arba sau-valios, laisve) ${ }^{55}$, arba dar kitaip -

${ }^{53}$ Beschluß des Ersten Senats des Deutschen Bundesverfassungsgerichts vom 15. Dezember 1965 (BverfGE 19, $342<348$ f.> ,Wencker“) 1 BvR 513/65.

54 ,Tačiau kad ir kokiu principu remiantis būtų apibrèžiama nesikišimo sritis - ar tai būtų prigimtinès teisès, ar teisių, naudos, kategorinio imperatyvo nustatomų normų, visuomeninès sutarties nepažeidžiamumo ar bet kuris kitas principas, kuriuo žmonès stengèsi paaiškinti ir pateisinti savo ịsitikinimus, - laisvė šia prasme reiškia laisvę „nuo kažko“. Berlin, I. Dvi laisvès sąvokos. Vertė A. Jokubaitis. Šiuolaikiné politiné filosofija: antologija. Sudarė J. Kis; vertė V. Radžvilas. Vilnius: Pradai, 1998, p. 61.

${ }_{55}$ Šis I. Kanto terminas lietuviškame vertime ne tik sunkiai pastebimas, bet ir savo gelmès požiūriu iš tikrujų neatskleidžiamas: Kant, I. Religija vien tik proto ribose. Vertė R. Plečkaitis. Vilnius: Pradai, 2000, p. 38. Čia verčiama „,savo valios laisvei“. Originalus tekstas: Kant, I. Die Religion innerhalb der Grenzen der blossen Vernunft. Herausgegeben und erläutert von J. H. von Kirchmann. Philosophische Bibliothek oder Sammlung der Hauptwerke der Philosophie alter und neuer Zeit. Siebenzehnter Band. Berlin: Verlag von L. Heimann, 1869, S. 25. Iš Kanto (kaip ir J. J. Rousseau) filosofijos darytina išvada, kad individo teisès ir laisvès neturi pozityvaus turinio, nes individas yra negatyvi laisvè, t. y. „laisvè nuo“: „Kanto laisvasis individas yra transcendentinè būtybė, esanti už gamtinio priežastingumo ribų. $<\ldots>$ Laisvė nuo baimès, meilès ar troškimo prisitaikyti reiškia laisvę nuo despotizmo to, ko negaliu kontroliuoti." Berlin I. Op. cit., p. 73-74. 
negatyviaja laisve ${ }^{56}$. Šiaip ar taip, reikia pabrèžti, kad ši tam tikra erdvè, laisva nuo valstybès (ir ne tik valstybès, bet ir kitų asmenų) kišimosi, palyginti su šios doktrinos gyvavimo pradžia, yra labai išsiplètusi, juridiškai plačiai garantuojama ir instituciškai saugoma kaip konstitucine $v e r t y b \dot{e}$, pavyzdžiui, šiuolaikinèje doktrinoje pripažistama, kad liberalios pagrindinès teisès ne tik interpretuojamos kaip valstybès valdžios kišimosi ribos, bet drauge jos ir ịpareigoja valstybę ginti ir užtikrinti konstituciškai saugomus teisinius gèrius, pavyzdžiui, pagrindinè susirinkimų laisvès teisè ne tik saugo nuo neleistino valstybės įsikišimo, bet ir îpareigoja ją imtis pozityvių veiksmų, kuriais suteiktų galimybę netrukdomai naudotis šia pagrindine teise, kaip antai saugodama nuo trukdymų ${ }^{57}$.

Net jeigu traibalizmą laikytume didžiausiu teisiniu anachronizmu, vis dèlto asmens teisių ribojimas galimas ne tik tada, kai jo teisė kertasi su kito asmens teise (liberalus požiūris), bet ir tada, kai valstybė siekia apginti tiek paskirą asmenį, tiek žmonių bendruomenę, jos gerovę ir viešają tvarką (tarsi traibalistinis požiūris). Net jeigu konstitucinę nuostatą pateiksime be konteksto, - „Valstybė <...> rūpinasi Lietuvos <..> vertybių apsauga" (Konstitucijos 42 straipsnio 2 dalis), - bus aišku, kad valstybejje konstituciškai objektyvi vertybių sistema tikrai turi būti ginama ne mažiau negu subjektyvi ${ }^{58}$. Neabejotina, kad šiuo principu vado-

${ }_{56}$ „Millis painiojo < .. > [tai], jog bet kuri prievarta yra bloga pati savaime, nes ji niekais paverčia žmogaus troškimus, net jei gali tekti ją taikyti tam, kad būtų užkirstas kelias kitoms, didesnèms blogybėms; tuo tarpu nesikišimas, esantis prievartos priešingybė, yra geras savaime, net jei jis ir nèra vienintelis gèris. Tai negatyvi laisvès samprata, klasikinè jos forma. < ..> „Negatyvioji laisve““ - tai dalykas, kurio mastą šiuo atveju sunku ịvertinti. Prima facie ji gali pasirodyti priklausanti nuo galios rinktis bent iš dviejų alternatyvų. Tačiau ne visi pasirinkimai vienodai ar iš viso yra laisvi.“ Berlin, I. Op. cit., p. 63, 65 .

${ }^{57}$ Adamovich, L. K.; Funk, B.-Ch., Holzinger, G. Österreichisches Staatsrecht 3. Grundrechte. Wien, New York: Springer-Verlag, 2004, S. 27.

${ }^{58}$ Antai Vokietijos Federalinis Konstitucinis Teismas yra konstatavęs, kad ,pagrindinių teisių paskirtis, be abejo, pirmiausia yra apsaugoti individo laisvès sriti nuo viešosios valdžios kišimosi; jos yra piliečio gynimosi nuo valstybės teisès. Tai kyla iš pagrindinių teisių idèjos istorinès dvasinès raidos, taip pat iš istorinių procesų, 
kurie vedè prie pagrindinių teisių inkorporavimo ị atskirų valstybių konstitucijas. Tokia yra ir Pagrindinio įstatymo pagrindinių teisių prasmè. I jo pradžią iškeliant pagrindinių teisių skyrių norèta pabrèžti žmogaus ir jo orumo pirmenybę prieš valstybès galią. Atitinkamai įstatymų leidèjas užtikrino ypatingą šių teisių gynimo teisinę priemonę - konstitucinį skundą tik dèl viešosios valdžios aktų. / Bet lygiai taip pat teisinga yra ir tai, kad Pagrindinis įstatymas, kuris nėra vertybiškai neutrali tvarka $\langle\ldots\rangle$, savo pagrindinių teisių skyriuje ịtvirtino objektyvią vertybių tvarką ir kad būtent taip yra išreiškiamas principinis pagrindinių teisių galiojimo galios sutvirtinimas $\langle\ldots>$. Šita vertybių sistema yra socialinèje bendruomenèje laisvai besivystančios žmogaus asmenybès ir jos orumo centras ir ji visoms teisès sritims turi būti pagrindinis konstitucinis orientyras; įstatymų leidybai, administracijai ir teisingumo vykdymui ji duoda kryptis ir impulsus." Urteil des Ersten Senats des Deutschen Bundesverfassungsgerichts vom 15. Januar 1958 (BVerfGE 7, $198<204$ f. $>$ Lüth) 1 BvR 400/51.

Vokietijos Federalinis Konstitucinis Teismas, žymiojoje Socialistinès reicho partijos (SRP) uždraudimo Vokietijoje byloje aiškindamas Pagrindinio įstatymo 21 straipsnio 2 dalyje įtvirtintą sąvoką ,laisvoji demokratinė santvarka“", konstatavo, kad demokratinejje valstybèje politinių partijų eliminavimas iš visos valstybės organizacijos yra pateisinamas ,tik tada, kai jos siekia sukrèsti aukščiausias pamatines laisvos demokratinès konstitucinès valstybès vertybes. Šios pamatinès vertybės sudaro laisvą demokratinę santvarką, kurią visoje „,konstitucingos tvarkos“valstybinèje santvarkoje Pagrindinis įstatymas traktuoja kaip fundamentalią. Galiausiai ši pamatinè tvarka dèl Pagrindiniame įstatyme realizuoto konstitucinio politinio sprendimo yra paremta vaizdiniu, kad kūrinijos sandaroje žmogus turi savitą autonomišką vertę, o laisvė ir lygybė yra valstybės nuolatinès pamatinès vertybès. Todèl [valstybès] santvarka yra vertybių susaistyta tvarka. Ji yra priešingybė totalinès valstybės, kuri, kaip išimtine viešpatavimo galia, atmeta žmogaus orumą, laisvę ir lygybę. SRP [atstovo] įsivaizdavimas, kad gali būti įvairių laisvosios demokratijos santvarkų, yra klaidingas.“ Urteil des Ersten Senats des Deutschen Bundesverfassungsgerichts vom 23. Oktober 1952 (BVerfGE 2, $1<12>$-SRP-Verbot) 1 BvB 1/51.

Taip pat ir sprendime dèl komunistų partijos uždraudimo Vokietijoje Federalinis Konstitucinis Teismas konstatavo, kad ,pasaulèžiūrų ir interesų ịvairovè valstybès bendros valios formavimo apskritai neturi padaryti neįmanomo, o tie, kurie yra pašaukti bendradarbiauti formuodami tą valią, turi mažų mažiausiai visiškai sutarti dẻl pritarimo pamatinėms konstitucinėms vertybèms. Galima įsivaizduoti, kad visuomeninè-politinė grupè egzistuoja ir veikia kaip politinė partija, kuri atmeta šias pamatines vertybes ir su jomis kovoja; tačiau negalima įsivaizduoti, kad jai konstituciškai galètų būti garantuotas atsakingas, teisiškai reikšmingas bendradarbiavimas formuojant valstybès valią." Urteil des Ersten Senats des Deutschen Bundesverfassungsgerichts vom 17. August 1956 (BVerfGE 5, 85<134> -KPD-Verbot) BvB 2/51. 
vaujasi tiek Lietuvos ${ }^{59}$, tiek pasaulio konstitucinès justicijos institucijos ir kiti teismai. Teismams vykdant teisingumą neretai tenka pareiga tarpusavyje pasverti paskiras konstitucines vertybes, kaip antai tėvų teisę auginti ir auklèti vaikus pagal savo įsitikinimus, religijos laisvę, netgi religinę taiką bei santarvę valstybèje ir, pavyzdžiui, žmogaus kūno neliečiamumą ${ }^{60}$. Todèl konstitucinis proporcingumo principas „negali nedalyvauti“ konstitucinių vertybių „svèrimo“ procese, t. y. teismui

Aukščiausi vertybiu tvarkos principai yra konstituciškai nekeičiami: „Pagrindiniame įstatyme yra įtvirtinta vertybių susaistyta tvarka, kuri riboja viešają valdžią. Šia tvarka turi būti užtikrintas žmogaus savarankiškumas, atsakingumas ir orumas valstybineje bendruomeneje $<\ldots>$. Aukščiausi šios vertybių tvarkos principai yra apsaugoti keičiant Konstituciją $<\ldots>$. [İstatymų leidejas] negali pažeisti Konstitucijos; Konstitucinè justicija kontroliuoja, kaip įstatymų leidejas laikosi Konstitucijos parametrų susaistymo." Urteil des Ersten Senats des Deutschen Bundesverfassungsgerichts vom 16. Januar 1957 (BVerfGE 6, $32<40$ f.>-Elfes-) 1 BvR 253/56.

59 „Konstitucija, kaip aukščiausios teisinès galios aktas ir visuomenès sutartis, yra grindžiama universaliomis, nekvestionuojamomis vertybėmis - suvereniteto priklausymu Tautai, demokratija, žmogaus teisių ir laisvių pripažinimu bei jų gerbimu, pagarba teisei bei teisės viešpatavimu, valdžios galių ribojimu, valdžios įstaigu priederme tarnauti žmonèms ir atsakomybe visuomenei, pilietiškumu, teisingumu, atviros, teisingos, darnios pilietinès visuomenès ir teisinès valstybès siekiu. Konstitucijoje yra nustatyti žmogaus ir valstybės santykių, viešosios valdžios formavimo ir funkcionavimo, Tautos ūkio, vietos savivaldos, kitų svarbiausių visuomenès ir valstybės gyvenimo santykių pagrindai." (Konstitucinio Teismo 2004 m. gegužès 25 d. nutarimo motyvuojamosios dalies II skyriaus 1 punktas. Valstybès žinios. 2004, Nr. 85-3094).

„Teise ir teisingumu grindžiamos demokratinès valstybès viena svarbiausių priedermių - gerbti, ginti ir saugoti tas vertybes, taip pat ir žmogaus teises ir laisves, kuriomis yra grindžiama pati Tautos priimta Konstitucija ir kurių realus ịtvirtinimas, gynimas ir apsauga yra pačios valstybès raison d'être." (Konstitucinio Teismo 2006 m. rugpjūčio 19 d. nutarimo motyvuojamosios dalies II skyriaus 1 punktas. Ibid., 2006, Nr. 90-3529, atitaisymas Nr. 137).

${ }^{60}$ Antai Kelno žemès teismas 2012 m. gegužès 7 d. sprendime (Az. 151 Ns 169/11) nagrinèjo baudžiamumo už vyriškosios lyties naujagimių apipjaustymą grynai religiniu pagrindu klausimą (Landgericht Köln. justiz-online. Prieiga per internetą: <http://www.lg-koeln.nrw.de/Presse/Pressemitteilungen/26_06_2012_Beschneidung.pdf $>$ ). 


\section{vykdant teisingumą ${ }^{61}$. Tačiau konstitucinès vertybès nèra paprasti teisi-}

${ }^{61}$ Konstitucinis proporcingumo principas - implicitinis konstitucinis principas, kurio turini oficialiai, galutinai ir neskundžiamai atskleidžia Konstitucinis Teismas, vadovaudamasis vien vidine Konstitucijos logika, tiesa, [daugelị kartų] pripažindamas ir Lietuvos teisès aiškinimo šaltinius, kaip antai Europos Žmogaus Teisių Teismo (pvz., Konstitucinio Teismo $2007 \mathrm{~m}$. gegužès $15 \mathrm{~d}$. nutarimo motyvuojamosios dalies III skyriaus 15 punktas. Valstybès žinios. 2007, Nr. 54-2097) bei Europos Sajungos Teisingumo Teismo (Konstitucinio Teismo $2011 \mathrm{~m}$. birželio $21 \mathrm{~d}$. nutarimo motyvuojamosios dalies IV skyriaus 7 punktas. Ibid., 2011, Nr. 76-3672) jurisprudenciją. Europos Žmogaus Teisių Teismas implicitinị konvencini proporcingumo principą taip pat išvede iš Žmogaus teisių ir pagrindinių laisvių apsaugos konvencijos dvasios, nes Europos Žmogaus Teisių Teismo praktikoje nepripažistamas formalus pažodinis Konvencijos nuostatų aiškinimas, tad pagal prasmę ir logiką jis turi sutapti ir su Konstitucijoje ịtvirtintu šio principo turiniu (Kūris, E. Ekstranacionaliniai veiksniai Lietuvos Respublikos Konstituciniam Teismui aiškinant Konstituciją. Teisè. 2004, Nr. 50, p. 83), nes šis principas išvestas ,naudojant tuos pačius metodus, kaip ir tarptautiniams teismams aiškinant Europos žmogaus teisių ir pagrindinių laisvių apsaugos konvenciją“(Kūris, E. Lietuvos Respublikos Konstitucija ir Europos teisès iššūkiai. Justitia. 2004, Nr. 6(54), p. 35). Vis dèlto, kaip rodo praktika, gali kilti nesuderinamumas tarp Konstitucijos dvasios ir Konvencijos dvasios, „,neproporcingumas“ tarp Konstitucijoje esančio [nekvestionuojamo] proporcingumo ir Konvencijos proporcingumo sampratų. Ir nors abu minėti teismai orientuojasi ,i tą patị principą“, ,,abipusiai draugiško aiškinimo“ idèja (Kūris, E. Lietuvos Respublikos Konstitucija ir Europos teisès iššūkiai. Justitia. 2004, Nr. 6(54), p. 35-36) kartais gali ir likti tik idejja. Antai Šveicarijos Federalinis Teismas yra konstatavęs, kad „EŽTT pagal jo paties nusistovejjusią jurisprudenciją nèra kompetentingas teisingai aiškinti ir taikyti nacionalinę teisę; visų pirma jam nepriklauso nacionalinės teisès [nesavavališką] interpretaciją valstybės viduje pakeisti sava interpretacija (tai aiškiai padaryta sprendimo Schlumpf priě̌ Šveicarija 111 ir 51 punktuose su gausybe nuorodų i jurisprudenciją). EŽTT tik peržiūri, ar nacionalinè teisè, kaip ji aiškinama ir taikoma paskutinès instancijos valstybinių vidaus institucijų (EŽTK 35 straipsnio 1 dalis), nepažeidžia Konvencijoje ittvirtintų teisių (EŽTK 32 ir 34 straipsniai)“ (sprendimo 7.3.3.1 punktas). „Kyla klausimas, ar tuo [t. y. atitinkamu sprendimu dèl Šveicarijos - T. B. pastaba] EŽTT neperžengè savo iggaliojimų [ribų], nustatytų EŽTK 16 ir 34 straipsniuose" (sprendimo 7.3.3.3 punktas). Žr. Urteil der II. sozialrechtlichen Abteilung des Schweizerischen Bundesgerichts vom 15. September 2010. BGE 137 I 86.

Antra vertus, negalima nesutikti su tuo, kad ,Europos Žmogaus Teisių Teismas tai fenomenalus žmonijos raidos laimejjimas. Jis ne deklaratyviai, o praktiškai tapo efektyvus ir pajègia, esant individualizmo ir kolektyvizmo koncepcijų dichotomijai, rinktis individualizmą išreiškiančią žmogaus teisių sampratos paradigmą.“ Mesonis, G. Žmogaus teisių apsaugos metodologija: Europos Žmogaus Teisių Teismas vs sociumo entropija. Logos. Nr. 80, (2014), p. 55. 
niai gèriai, kuriuos būtų galima „vartyti“ kaip panorèjus. Žmogaus teisès yra konstitucijos gyvybès šaltinis, tai, dèl ko konstitucija egzistuoja, konstitucijos ir jos nuostatų conditio sine qua non. Žmogaus teisès yra konstitucijos tikslas, todèl jos yra ir iš konstitucijos kylančiu santykiu determinantas, tikslas, principas ir norma. Šiuo požiūriu žmogaus teisès negali būti traktuojamos kaip konstituciniu santykiu (ne konstitucinio reguliavimo) objektas, net jeigu paskiras konstitucines žmogaus teises tenka sverti tarpusavyje ${ }^{62}$. Bet kokiu atveju galutinị sprendimą konstitucinių vertybių „svèrimo“ procese priima ne įstatymų leidejjas, o būtent teismas ${ }^{63}$.

Kaip jau minèta, Konstitucinis Teismas 1999 m. spalio 6 d. nutarime yra konstatavęs, kad nuo reguliuojamų visuomeninių santykių specifikos priklauso ir teisinio reguliavimo ypatumai. Konstitucinių santykių ypatumas tas, kad jie yra ius supremum reguliuojami santykiai. O tai reiškia, kad galimybès reglamentuoti šiuos santykius jų objekto, arba dalyko, atžvilgiu yra potencialiai neribotos (pirmiausia žvelgiant konstituciniu lyginamuoju ir istoriniu aspektu), ir tuo pasireiškia konstitucinių santykių objekto apibrėžtumo reliatyvumas, kai tik bandoma ji kaip nors klasifikuoti. Konstituciniai santykiai visada

62 Plačiau apie tai G. Mesonio straipsnyje, kuriame analizuojama socialinès atsakomybès ir saviraiškos laisvės santykio, akademinès ir saviraiškos laisvès santykio problema, apskritai saviraiškos ir orumo santykio, kuris reikalingas pusiausvyros, problema. Žr. Mesonis, G. Diskursas bylos Mustafa Erdoğan v. Turkey kontekste: Saviraiškos laisvè v. Akademinė atsakomybè. Logos. Nr. 84 (2015), p. 84.

63 ,Analizuojant moralinių argumentų objektyvumą pagrịstai pastebima, kad „,vienareikšmio bet kurios moralès (dorovès) problemos sprendimo nėra“. O galimų sprendimų modelių gausa tèra objektyviai egzistuojanti subjektyvumų visuma. Pažymėtina ir tai, kad teisę suvokiant per teisinio pozityvizmo prizmę, nederètų dirbtinai supriešinti filosofinio materializmo ir filosofinio idealizmo. Atvirkščiai, pozityvi teisès norma jos kūrèjo valia yra visuomet subjektyvaus filosofinio idealizmo atspindys. B. Celano pabrěžia, kad tokia dichotomija yra rimta problematika teisiniame diskurse ir kad galiausiai teisejjui tenka priimti galutini sprendimą. Mes galètume autorių papildyti, pripažindami, kad autoriaus minima dichotomija formuoja galutinio arbitro poreiki.." Mesonis, G. Teisinio diskurso dialektika. Logos. Nr. 67 (2011), p. 18. 
yra daugiapoliai, nes jie yra daugiamačiai, visada susipynę, o teismas, spręsdamas dèl vienos konstitucinès teisès ar laisvès, automatiškai nagrinèja ir su kitomis teisèmis ir laisvėmis susijusius klausimus. [Konstitucinès] teisminès kontrolès dalykas faktiškai gali būti bet kas. Dèl to neịmanoma konstitucinių santykių objektų sugrupuoti pagal kokius nors kriterijus. Konstitucinès teisès reglamentuojamų santykių ypatumas - jų neribotumas. Konstitucinių santykių subjektų ratas taip pat yra neribotas. Šių santykių turinys, arba santykių subjektų tarpusavio sąveika, yra neatsiejama nuo konstitucinėse nuostatose (aukščiausiosios teisès šaltinių eksplicitinių ir implicitinių principų ir normų) $)^{64}$ ịtvirtinto šių santykių subjektų konstitucinio statuso ir konstitucinių vertybių igyvendinimo, apsaugos ir gynimo. Pagrindinis kriterijus, pagal kurị nustatoma, ar santykis tarp teisès subjektų yra konstitucinis, ar ordinarinis teisinis, yra santykio reguliavimo aukščio dimensija, t. y. aukščiausio, konstitucinio lygmens nuostatų apibrěžiamas santykis, santykis hochheitlicher Natur ${ }^{65}$ (suverenios prigimties) yra konstitucinis santykis. „<...> „viršesnès“ už tuos, kuriuos normos ịpareigoja arba kuriems jos suteikia teises, iš tikrųjų yra tik pareigas nustatančios bei teises suteikiančios normos, o ne normas kuriantys arba taikantys individai, nes pastarieji patys yra pavaldūs teisinei tvarkai, būtent normoms, ịgalinančioms jų funkcijas. <...> teisinės tvarkos normos ịsako, igalina arba pozityviai leidžia individų elgesị. "66 Teisès subjektų tarpusavio santykiai yra vienodai determinuojami aukščiausiosios teisès nuostatų nustatytos teisinès tvarkos, kuri juos ịpareigoja, jiems leidžia arba draudžia tam tikrą veikimą. Tautos steigiamuoju aktu konstituojama teisine tvarka, jos priimta konstitucija net sukuria tam tikrų asmenų teisini

${ }^{64}$ Plg.: Kelsen, H. Grynoji teisès teorija. Vertė A. Degutis, E. Kūris. Vilnius: Eugrimas, 2002, p. 155.

${ }^{65}$ Novak, R. Lebendiges Verfassungsrecht. Forschungen aus Staat und Recht. Band 159. Herausgeber: Raschauer, B. Wien: Springer-Verlag, 2008, S. 68.

${ }^{66}$ Kelsen, H. Op. cit., p. 154-155. 
subjektiškumą ${ }^{67}$. Tad ir šiuo požiūriu konstitucinių santykių subjektų ratas yra neribotas.

\section{Išvados}

Šiame straipsnyje siekta atskleisti konstituciniu santykiu specifiką konstitucinès teisès sampratos kontekste ir atsakyti ị klausimą, ar įmanoma suformuluoti teisiškai pakankamą ir korektišką konstitucinių santykiu definiciją apimant visus jų elementus, kurių (ypač objekto) analizè straipsnyje taip pat neapeinama. Tad šio tyrimo rezultatus galima apibendrinti taip:

${ }^{67}$ Be tautos steigiamojo akto - aukščiausiosios teisès tokio reglamentavimo dalyko $i s ̌$ viso nebūtų. Tą patvirtina ir tai, kad mums nèra žinoma kita valstybè, kurioje būtų, pvz., trejopas bažnyčių statusas, maža to, ịtvirtintas konstituciniu lygmeniu, nors bažnyčia kai kuriose valstybèse gyvuoja tūkstantmečiu ilgiau nei Lietuvoje, tačiau jų pozityviojoje teisèje ,tradicinès“ bažnyčios neišskiriamos, todèl tradiciškumas šiame kontekste pats savyje nèra visuotine objektyvi duotybė: „Konstitucija įtvirtina trejopą Lietuvoje veikiančių bažnyčių bei religinių organizacijų statusą: vienos bažnyčios bei religinès organizacijos yra tradicinès Lietuvoje, kitos (tradicinėmis Lietuvoje nesančios) bažnyčios bei religinès organizacijos yra valstybės pripažintos, dar kitos Lietuvoje veikiančios bažnyčios bei religinès organizacijos neturi nei tradicinių Lietuvoje, nei valstybės pripažintų statuso.“ (Konstitucinio Teismo 2007 m. gruodžio 6 d. sprendimo motyvuojamosios dalies II skyriaus 6 punktas. Valstybès žinios. 2007, Nr. 129-5246). Taigi toks trejopo bažnyčių bei religinių organizacijų statuso sukūrimas reiškia ir trejopų konstitucinių santykių sukūrimą. H. Kelseno koncepcijoje būtent ir nurodoma, kad, ,teisinis santykis yra ne socialinèje tikroveje jau egzistuojantis faktinis santykis, kurị teisès normos tik reguliuoja, bet toks santykis, kurị konstituoja būtent teisès normos“ (Kelsen, H. Op. cit., p. 156). Taigi konstituciniai santykiai nèra ,tiesiog“ teisiniai santykiai. Konstitucija - tai steigiamosios, o ne issteigtosios valdžios aktas. Konstitucinio Teismo aktai nèra ordinarinio lygmens, juose atskleidžiama tai, kas yra Konstitucijoje - pirminiame steigiamajame akte. Šiais aktais nauji konstituciniai santykiai konstituojami ne ex nihilo (pvz., konkrečią religiją išpažįstančių asmenų socialinė grupè veikia dar iki Konstitucijos, kurioje įtvirtinamas tos religijos ar jos išpažinejjų grupès statusas, prièmimo), bet kokybiškai naujai ab initio, pvz., iki $1992 \mathrm{~m}$. spalio 25 d. referendumo Lietuvos teisès istorijoje buvusios niekam visiškai nežinomos ,,valstybés pripažintos tradicinès bažnyčios ir religinès organizacijos" vèliau tapo plataus konstitucinio teisinio statuso viešaisiais juridiniais asmenimis. 
a) nors [ypač ir pirmiausia] ordinarinei teisei reikalingos aiškiai suformuluotos galutinès definicijos, tačiau pateikti kai kurių konstitucinių sąvokų apibrèžtis gali būti nelengva. Kaip tik viena tokių sąvokų yra „konstituciniai santykiai“, nes jos apibrèžties negalima formuluoti remiantis „ortodoksine“ konstitucinès teisès samprata. Jeigu mėgintume suformuluoti universalią konstitucinių santykių apibrèžti, ji neišvengiamai taptų neišsami, netobula ar klaidinga;

b) konstituciniu santykiu pagrindas modernios konstitucinès teisès paradigmos požiūriu yra konstitucinès teisès, kaip aukščiausiosios teisès, šaltiniai, todèl jų pagrindas nèra ordinarinè teisè. Kaip aukščiausioji [konstitucinè] teisè negali būti neteisè, taip ir konstituciniai santykiai negali būti neteisiniai, todèl terminas „konstituciniai santykiai“ savaime laikytinas pakankamu, o papildymas sąvoka „teisiniai“ yra perteklinis;

c) konstituciniai santykiai, turint omenyje juose dalyvaujančius subjektus, iš pirmo žvilgsnio atrodo esą $d v i p o l i a i$, tačiau dèl savo konstitucinès prigimties jie visada yra daugiapoliai, nes savo turinyje ị vieną tinklą kompleksiškai sujungia ịvairių konstitucinių vertybių koreliaciją ir konstitucinių santykių subjektų daugetą. Tačiau konkrečios konstitucinès bylos kontekste procesiniu požiūriu konstituciniai santykiai gali būti tarp dviejų subjektų, kaip atsirandantys iš teisių ir pareigų santykio ginčo. O konstituciniai santykiai in abstracto jie yra todèl, kad išsiskiria jų teisinio reguliavimo aukščio dimensija. Šiuo požiūriu konstituciniai santykiai - tai fundamentaliai (Konstitucijos ir konstitucinés jurisprudencijos lygmeniu) reglamentuojamų pamatinių santykių visuma.

\section{Literatūra}

Adamovich, L. K.; Funk, B.-Ch.; Holzinger G. Österreichisches Staatsrecht 3. Grundrechte. Wien, New York: Springer-Verlag, 2004.

Aulehner, J. Grundrechte und Gesetzgebung. Jus Publicum. Bd. 203. Tübingen: Mohr Siebeck, 2011. 
Barak, A. Teismo diskrecijos prigimtis ir jos reikšmè vykdant teisingumą. Vertė R. Naujokaitis. Justitia. 2005, Nr. 3(57).

Berlin, I. Dvi laisvės sąvokos. Vertė A. Jokubaitis. Šiuolaikinè politiné filosofija: antologija. Sudarè J. Kis; vertė V. Radžvilas. Vilnius: Pradai, 1998.

Beschluß des Ersten Senats des Deutschen Bundesverfassungsgerichts vom 15. Dezember 1965 (BverfGE 19, $342<348$ f.> „Wencker"). 1 BvR 513/65.

Beschluß des Ersten Senats des Deutschen Bundesverfassungsgerichts vom 27. November 1990 (BVerfGE 83, $130<143$ f.> Josephine Mutzenbacher) - 1 BvR 402/87.

Esmein, A. Konstitucinès teisès principai (prancüzų ir palyginamieji). T. 1, d. 1. Kaunas: Teisininkų draugijos leidinys, 1932.

Grundgesetz für die Bundesrepublik Deutschland vom 23. Mai 1949. BGBl. S. 1.

Häfelin, U.; Haller, W. Schweizerisches Bundesstaatsrecht. Die neue Bundesverfassung. 6., stark überarbeitete Auflage. Zürich, Basel, Genf: Schulthess Juristische Medien AG, 2005.

Hesse, K. Grundzüge des Verfassungsrechts der Bundesrepublik Deutschland. Neudruck der 20. Auflage. Heidelberg: C. F. Müller Verlag, 1999.

Jarašiūnas, E. Aukščiausioji ir ordinarinè teisè: požiūrio ị konstituciją pokyčiai. Jurisprudencija. 2002, [t.] 33(25).

Jarašiūnas, E. Jurisprudencinè konstitucija. Jurisprudencija. 2006, [t.] 12(90).

Jarašiūnas, E. Konstitucija ir įstatymas: kelios interpretavimo problemos. Konstitucijos aiškinimas ir tiesioginis taikymas. Sudare V. Rinkevičius. Vilnius: Lietuvos Respublikos Konstitucinis Teismas, 2002.

Jarašiūnas, E. Konstitucinė kontrolè: keletas minčių apie žmogaus teisių apsaugos matmenị. Konstitucine jurisprudencija. 2009, Nr. 4(16).

Jarašiūnas, E. Konstitucinè teisè - nacionalinès teisès sistemos branduolys ir teisès sistemą integruojanti teisès sritis. Lietuvos konstitucine 
teisè. Vadovèlio parengimo koordinatorius E. Jarašiūnas. Vilnius: Lietuvos teisès universitetas, 2001.

Jarašiūnas, E. Teisminès valdžios organizacijos ir veiklos konstitucinès problemos (teisminès valdžios visavertiškumas, teismų sistemos bei teisejjų ir teismų nepriklausomumas). Lietuvos konstitucine teisé: raida, institucijos, teisiu apsauga, savivalda: kolektyvinè monografija. Vilnius: Mykolo Romerio universitetas, 2007.

Kant, I. Die Religion innerhalb der Grenzen der blossen Vernunft. Herausgegeben und erläutert von J. H. von Kirchmann. Philosophische Bibliothek oder Sammlung der Hauptwerke der Philosophie alter und neuer Zeit. Siebenzehnter Band. Berlin: Verlag von L. Heimann, 1869.

Kant, I. Religija vien tik proto ribose. Vertė R. Plečkaitis. Vilnius: Pradai, 2000.

Kelno žemès teismo $2012 \mathrm{~m}$. gegužès $7 \mathrm{~d}$. sprendimas Az. 151 Ns 169/11, Landgericht Köln. justiz-online. Prieiga per internetą: <http:// www.lg-koeln.nrw.de/Presse/Pressemitteilungen/26_06_2012_-_ Beschneidung.pdf $>$.

Kelsen, H. Grynoji teisès teorija. Vertè A. Degutis, E. Kūris. Vilnius: Eugrimas, 2002.

Kūris, E. Ekstranacionaliniai veiksniai Lietuvos Respublikos Konstituciniam Teismui aiškinant Konstituciją. Teisè. 2004, [t.] 50.

Kūris, E. Europos Sąungos teisè Lietuvos Respublikos Konstitucinio Teismo jurisprudencijoje: sambūvio algoritmo paieškos. Teise besikeičiančioje Europoje: Liber Amicorum Pranas Kūris. Ats. red. S. Katuoka. Vilnius: Mykolo Romerio universitetas, 2008.

Kūris, E. Konstitucija kaip teisė be spragų. Jurisprudencija. 2006, [t.] 12(90).

Kūris, E. Konstitucijos dvasia. Jurisprudencija. 2002, [t.] 30(22).

Kūris, E. Konstitucinė justicija Lietuvoje: pirmasis dešimtmetis. Justitia. 2003, Nr. 3-4(45-46).

Kūris, E. Konstitucinè teise kaip jurisprudencine teisé: konstitucinè justicija ir konstitucines teises paradigmos transformacija Lietuvoje: 
habilitacijos procedūrai teikiamų mokslo darbų apžvalga: socialiniai mokslai, teisè (01S). Vilnius: Vilniaus universiteto leidykla, 2008.

Kūris, E. Lietuvos Respublikos Konstitucija ir Europos teisès iššūkiai. Justitia. 2004, Nr. 6(54).

Küris, E. Teismo precedentas kaip teisės šaltinis Lietuvoje: oficiali konstituciné doktrina, teisinio mąstymo stereotipai ir kontrargumentai. Jurisprudencija. 2009, [t.] 2(116).

La Constitution du 4 octobre 1958 à jour au 23 juillet 2008. Prieiga per internetą: <http://www.conseil-constitutionnel.fr/conseil-constitutionnel/francais/la-constitution/la-constitution-du-4-octobre-1958/ texte-integral-de-la-constitution-de-1958.5074.html>.

Leonas, P. Teisè ir dora. Leonas, Petras. Raštai. T. 3. Teisine publicistika; Pergyvenimai ir atsiminimai; Teisinis palikimas; Bibliografija. Sudare V. Andriulis. Vilnius: Teisinès informacijos centras, 2005.

Lietuvos Respublikos Konstitucija. Valstybès žinios. 1992, Nr. 331014. Pakeitimai: ibid., 1996, Nr. 64-1501, 122-2863; 2002, Nr. 65-2629; 2003, Nr. 14-540, 32-1315, 32-1316; 2004, Nr. 111-4123, 111-4124; 2006, Nr. 48-1701.

Lietuvos Respublikos Konstitucinio Teismo 2003 m. gegužès 30 d. nutarimas. Valstybès žinios. 2003, Nr. 53-2361.

Lietuvos Respublikos Konstitucinio Teismo 2004 m. gegužès 25 d. nutarimas. Valstybès žinios. 2004, Nr. 85-3094.

Lietuvos Respublikos Konstitucinio Teismo 2004 m. liepos 1 d. nutarimas. Valstybès žinios. 2004, Nr. 105-3894.

Lietuvos Respublikos Konstitucinio Teismo 2004 m. gruodžio 13 d. nutarimas. Valstybès žinios. 2006, Nr. 181-6708. Lietuvos Respublikos Konstitucinio Teismo $2005 \mathrm{~m}$. rugsejo $20 \mathrm{~d}$. sprendimas. Valstybès žinios. 2006, Nr. 113-4132.

Lietuvos Respublikos Konstitucinio Teismo 2006 m. kovo 14 d. nutarimas. Valstybès žinios. 2006, Nr. 30-1050.

Lietuvos Respublikos Konstitucinio Teismo 2006 m. kovo 28 d. nutarimas. Valstybès žinios. 2006, Nr. 36-1292. 
Lietuvos Respublikos Konstitucinio Teismo 2006 m. rugpjūčio 19 d. nutarimas. Valstybės žinios. 2006, Nr. 90-3529, atitaisymas Nr. 137.

Lietuvos Respublikos Konstitucinio Teismo 2007 m. gegužès 15 d. nutarimas. Valstybès žinios. 2007, Nr. 54-2097.

Lietuvos Respublikos Konstitucinio Teismo 2007 m. gruodžio 6 d. sprendimas. Valstybès žinios. 2007, Nr. 129-5246.

Lietuvos Respublikos Konstitucinio Teismo 2008 m. sausio $21 \mathrm{~d}$. nutarimas. Valstybés žinios. 2008, Nr. 10-349.

Lietuvos Respublikos Konstitucinio Teismo 2010 m. lapkričio 9 d. nutarimas. Valstybès žinios. 2010, Nr. 133-6800.

Machovenko, J. Aristokratinei valstybei alternatyvių junginių teisès vaidmuo igyvendinant teisinès valstybès doktriną Lietuvos Didžiojoje Kunigaikštystèje. Jurisprudencija. 2010, [t.] 3(121).

Mesonis, G. Diskursas bylos Mustafa Erdoğan v. Turkey kontekste: Saviraiškos laisvè v. Akademinè atsakomybè. Logos. Nr. 84 (2015).

Mesonis, G. Kai kurie konstituciniai valstybės ir bažnyčios santykių aspektai. Konstitucine jurisprudencija. 2008, Nr. 2(10).

Mesonis, G. Konstitucija monocentrinèje teisès sistemoje. Konstitucine jurisprudencija. 2008, Nr. 4(12).

Mesonis, G. Konstitucijos interpretavimo metodologiniai pagrindai: monografija. Vilnius: Registrų centras, 2010.

Mesonis, G. Teisinio diskurso dialektika. Logos. Nr. 67 (2011).

Mesonis, G. Vèliava - Flag - Drapeau, arba ir vèl apie žmogaus teises. Teise. T. 83 (2012).

Mesonis, G. Žmogaus teisių apsaugos metodologija: Europos Žmogaus Teisių Teismas vs sociumo entropija. Logos. Nr. 80 (2014).

Novak, R. Lebendiges Verfassungsrecht. Forschungen aus Staat und Recht. Band 159. Herausgeber: Raschauer, B. Wien: Springer-Verlag, 2008.

Roizijus, P. Lietuvos sprendimai, 1563. Sudarè V. Andriulis; vertė D. Dilytė. Vilnius: Teisinès informacijos centras, 2007. 
Spruogis, E. Teisiniai santykiai. Teises teorijos j̧vadas: vadovèlis: Liber amicorum prof. dr. Egidijui Jarašiūnui - 60. 2-asis pataisytas leidimas. Moksliniai redaktoriai: L. Baublys, E. Spruogis. Vilnius: Mes, 2012.

Urteil des Ersten Senats des Deutschen Bundesverfassungsgerichts vom 23. Oktober 1952 (BVerfGE 2, $1<12>-S R P$-Verbot) 1 BvB 1/51.

Urteil des Ersten Senats des Deutschen Bundesverfassungsgerichts vom 17. August 1956 (BVerfGE 5, 85<134>-KPD-Verbot) BvB 2/51.

Urteil des Ersten Senats des Deutschen Bundesverfassungsgerichts vom 16. Januar 1957 (BVerfGE 6, $32<40$ f.> -Elfes-) 1 BvR 253/56.

Urteil des Ersten Senats des Deutschen Bundesverfassungsgerichts vom 15. Januar 1958 (BVerfGE 7, $198<204$ f.> Lüth) 1 BvR 400/51.

Urteil des Ersten Senats des Deutschen Bundesverfassungsgerichts vom 15. Februar 2006 (BVerfGE 115, $118<151$ ff.> Luftsicherheitsgesetz) 1 BvR 357/05.

Urteil der II. sozialrechtlichen Abteilung des Schweizerischen Bundesgerichts vom 15. September 2010. BGE 137 I 86.

Umbach, D. C.; Clemens, T.; Dollinger, F.-W. Bundesverfassungsgerichtsgesetz. Mitarbeiterkommentar (Heidelbergerkommentar). 2, völlig neu bearbeitete Auflage. Heidelberg: C. F. Müller, 2005.

Žiobienè, E. Konstitucinès teisès samprata. Lietuvos konstitucine teisè: vadovèlis: Liber Amicorum Juozui Žiliui. Red. kolegija: E. Jarašiūnas, et al. Vilnius: Mykolo Romerio universitetas, 2012.

\section{CONSTITUTIONAL RELATIONS}

\section{TOMAS BLINSTRUBis}

\section{Summary}

Keywords: Constitution; jurisprudence of the Constitutional Court; constitutional relations; legal relations. 
The aim of this article is to disclose the specificity of constitutional relations in the context of the modern paradigm of constitutional law and to answer a question whether it is feasible to formulate a legally satisfactory and correct definition of constitutional relations, by embracing all their elements, the analysis of which (particularly, that of an object) is not left out in the article. The legal problems that the article attempts to examine are narrowed down to several relatively independent, although closely interrelated, groups of questions. One of those groups comprises questions arising from the theoretical concept of constitutional relations and the analysis of the contents of these relations. Methodologically following the paradigm of constitutional law as the state's supreme law, the underlying thesis is formulated, whereby the relations arising from the Constitution are always legal relations (meanwhile, legal relations are, certainly, not always constitutional ones); it is demonstrated that the determination of constitutional relations is legally satisfactory and that it does not require one to define those relations additionally as legal ones. Another group of problem-related questions covers questions that pertain to fundamental rights of a person. In the article it is maintained that fundamental rights, as rights that existed before the state came into being and that are above positive law, do not constitute any "pure" element of the contents of constitutional relations, or, let alone, any object of these relations, whereas they form a foundation for constitutional relations and are a determinant of these relations and a constitutive element within them, which cannot be detached from the idea of constitutionalism itself. Such a breakdown of the problem-related research issues highlights the premise on which this article is based: relations among a person, associations of persons and a state must be subordinated to the sole supreme law harmonising the interaction of these elements-the Constitution (including jurisprudential law). This means that the said relations in themselves do not extend beyond the Constitution, i.e. beyond the boundaries of its legal power and system of values; therefore, the relations regulated by supreme (formal and jurisprudential) law, though not by ordinary law, are constitutional ones. An attempt to formulate a universal definition of constitutional relations would, nonetheless, produce an incomprehensive, defective or erroneous result. The relations at issue are constitutional ones in $a b$ stracto due to the outstanding dimension of highness of their legal regulation. Thus, constitutional relations are the totality of general basic legal relations regulated in a fundamental manner (by "Grundnorm" and constitutional jurisprudence).

Iteikta 2017 m. gegužès $28 d$. 